\title{
CONCESSION POLICY OF THE SOVIET UNION IN AGRICULTURE: A REVIEW OF THE RECENT HISTORIOGRAPHY
}

\author{
Ol'ga V. Erokhina \\ Moscow Pedagogical State University, Moscow, Russian Federation
}

\begin{abstract}
Introduction. The article analyzes the issues of agricultural concession presented in the works of Russian researchers Maxim Matveyevich Zagorulko, Vladimir Viktorovich Bulatov and German historian Marina Schmider. Methods and materials. The monographs are significantly complemented by the already known works on concession policy and practice, as the authors introduce a significant number of new sources and statistics from German and Russian archives and libraries. To provide an objective analysis of the scientific works, the author uses the historical-system and historical-comparative methods. Analysis. The Russian researchers analyze the economic activities of four agricultural concessions: "Druzag", "Manych", "Druag", "Prikumskoye Russo-American Partnership". They identified factors that influenced the increase or decrease in profitability of the enterprises. M. Schmider focused her attention on changing the attitude of the government and business circles of Germany to the concession policy pursued in the USSR. In addition, it reveals the role of German agricultural concessions in the development of the German economy. The author identified mechanisms of influence on the Soviet leadership, which were used to facilitate the activities of two large agricultural concessions - Manych-Krupp and Druzag. It should be noted that the memoirs of German employees of agricultural concessions helped to recreate the life and activity of Soviet and German workers and employees, compare their working conditions, describe the relationship with the local population and government officials. Results. The authors conclude that the effective management methods and economic activities of these concessions contributed to increasing their competitiveness in comparison with similar Soviet enterprises. However, the activities of the concessions depended not only on the interest of the Soviet leadership in them, but also on the foreign policy relations of Germany and the Soviet state.

Key words: agricultural concession, Soviet Union, Germany, trade Union, Soviet power, historiography.

Citation. Erokhina O.V. Concession Policy of the Soviet Union in Agriculture: A Review of the Recent Historiography. Vestnik Volgogradskogo gosudarstvennogo universiteta. Seriya 4. Istoriya. Regionovedenie. Mezhdunarodnye otnosheniya [Science Journal of Volgograd State University. History. Area Studies. International Relations], 2021, vol. 26, no. 2, pp. 133-142. (in Russian). DOI: https://doi.org/10.15688/jvolsu4.2021.2.10
\end{abstract}

УДК 930(23)

ББК 63.3(2)6-2

Дата поступления статьи: 22.10.2019

Дата принятия статьи: 01.08.2020

\section{КОНЦЕССИОННАЯ ПОЛИТИКА СССР В СЕЛЬСКОМ ХОЗЯЙСТВЕ: ОБЗОР НОВЕЙШЕЙ ИСТОРИОГРАФИИ}

\author{
Ольга Викторовна Ерохина \\ Московский педагогический государственный университет, г. Москва, Российская Федерация
}

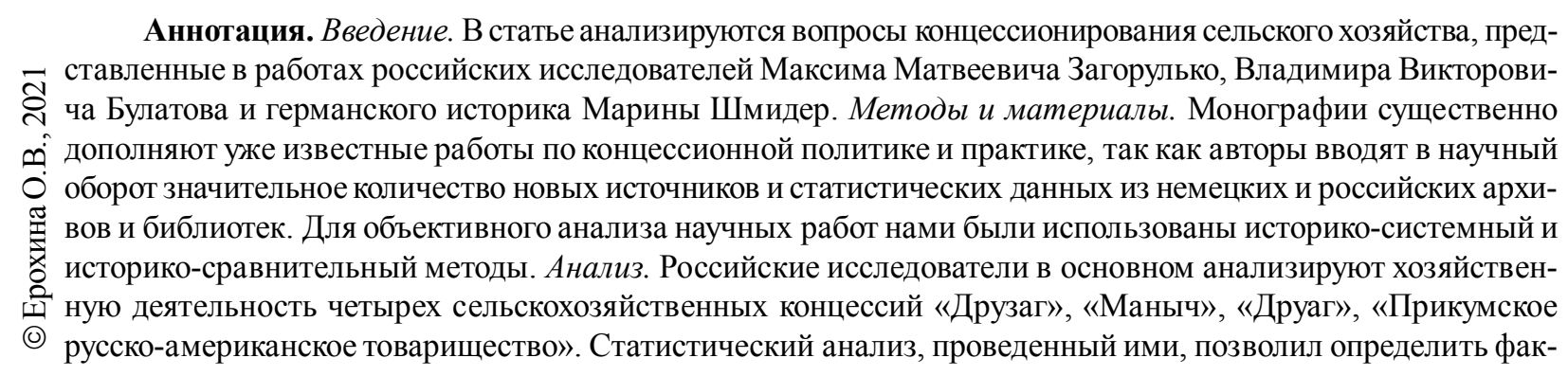


торы, влиявшие на повышение или понижение рентабельности предприятий. М. Шмидер сосредоточила внимание на изменении отношения правительства и предпринимательских кругов Германии к концессионной политике, проводимой в СССР. Кроме того, раскрывается роль немецких сельскохозяйственных концессий в развитии германской экономики. Немецким историком выявлены механизмы воздействия на советское руководство, которое они использовали, чтобы облегчить деятельность двум крупным сельскохозяйственным концессиям - «Маныч-Крупп» и «Друзаг». Следует отметить, что воспоминания немецких сотрудников сельскохозяйственных концессий помогли воссоздать жизнь и быт советских и немецких рабочих и служащих, сравнить их условия труда, описать взаимоотношения с местным населением и представителями власти. Результаты. Авторы делают вывод, что эффективные методы управления и хозяйственная деятельность этих концессий способствовали повышению их конкурентоспособности по сравнению с аналогичными советскими предприятиями. Однако деятельность концессий зависела не только от заинтересованности в них советского руководства, но и от внешнеполитических отношений Германии и Советского государства.

Ключевые слова: сельскохозяйственная концессия, СССР, Германия, профсоюз, советская власть, историография.

Цитирование. Ерохина О. В. Концессионная политика СССР в сельском хозяйстве: обзор новейшей историографии // Вестник Волгоградского государственного университета. Серия 4, История. Регионоведение. Международные отношения. - 2021. - Т. 26, № 2.-C. 133-142. - DOI: https://doi.org/10.15688/jvolsu4.2021.2.10

Введение. В конце XX - начале XXI в. внимание российских ученых было сосредоточено на изучении концессионной политики СССР, проводившейся в 1920-1930-е годы. Это было обусловлено рассекречиванием архивных документов и возрастанием интереса к хозяйственным механизмам периода НЭПа. Кроме того, исследователей интересовал концессионный опыт Советского государства в развитии экономики в связи с ростом численности предприятий с участием иностранного капитала в России в конце 1990-х - начале 2000-х годов. В последнее время наблюдается спад исследовательского интереса к данной проблематике.

Обсуждение. О концессионной политике Советского государства написано немало работ. Российские исследователи в основном акцентировали внимание на изучении правового регулирования концессионной практики; выявлении особенностей концессионного законодательства; деятельности концессионных предприятий в отдельных отраслях промышленности и механизмах их функционирования; социально-экономическом положении рабочих и служащих на них; формах, причинах и способах урегулирования трудовых конфликтов между концессионерами и работниками [2-4; $7-9 ; 10 ; 12 ; 13 ; 15-17]$.

Незначительная часть работ посвящена деятельности иностранных сельскохозяйственных концессий. Впервые эта проблема была поднята Ю.Б. Рагером в 1994 г. на международной конференции в Москве, где он выступил с докладом о деятельности герман- ской концессии «Друзаг» в Ванновском немецком районе Северо-Кавказского края [14]. В 1999 г. ставропольский историк Т.Н. Плохотнюк вновь обратилась к этой теме [11]. Опираясь на российские архивные материалы, они проанализировали причины и условия возникновения концессий на Северном Кавказе.

Затем в 2004 г. на материалах российских и немецких архивов Д.А. Марьиным рассмотрено экономическое сотрудничество России и Германии на примере фирмы «Фридриха Круппа» [9]. Несомненным плюсом этой работы является привлечение материалов немецких архивов и библиотек.

Также опубликованы работы, в которых исследователи охарактеризовали хозяйственно-правовую и социально-политическую деятельность германских сельскохозяйственных концессий «Маныч», «Друзаг» и «Друаг» от момента их создания до ликвидации [2-6]. В 2012 г. Е.Г. Ширяева в своем диссертационном исследовании сравнила положение и функционирование иностранных сельскохозяйственных концессий на Северном Кавказе в 1920-1930-е и 1990-2000-е гг. [15].

Из немецких исследователей к изучению этой темы первым обратился К.Х. Шларп в 1996 г., который на основе немецких источников описал условия образования концессий «Друзаг» и «Маныч», проанализировал взаимоотношения концессионеров и советских органов власти [20]. В 2016 г. М. Шмидер опубликовала биографическую статью, посвященную Фритцу Дитлову (в работах встречаются разные варианты на- 
писания фамилии: Диттлофф, Дитлоф, Дитлов), уделив внимание его деятельности в качестве директора на концессии «Друзаг» [19]. На следующий год она издала монографию по немецким сельскохозяйственным концессиям «Друаг», «Друзаг» и «Маныч» (см.: [9]).

Методы и материалы. Для объективного анализа работ мы использовали специальные исторические методы - системный и сравнительный. С их помощью были выделены основные проблемы, на которых сконцентрировали свое внимание исследователи и определили степень их изученности.

Анал из. С начала 2000-х гг. издано значительное количество работ по концессионным отношениям в Советской России. Большое внимание уделялось концессионным предприятиям в лесной, нефтяной и рыбной промышленности, угле- и золотодобыче, но почему-то сельскохозяйственные предприятия оказались менее изученными. В основном по этой теме опубликованы статьи, но есть и несколько крупных работ.

Из российских исследований мы отметим труд волгоградских ученых М.М. Загорулько и В.В. Булатова [6]. Это была первая работа, наиболее полно раскрывающая сложный механизм взаимоотношений между государственными органами власти и иностранцами на примере наркомземовских концессий.

М.М. Загорулько и В.В. Булатов провели анализ на примере сельскохозяйственных концессий «Маныч», «Друаг», «Друзаг», «Прикумское русско-американское товарищество», располагавшихся в южных и юго-восточных районах Советской России. Из девяти глав исследования шесть посвящены сельскохозяйственным концессиям, а оставшиеся - водным предприятиям, которые мы рассматривать не будем.

К сожалению, в работе М.М. Загорулько и В.В. Булатова отсутствует классический раздел научного исследования, где была бы отражена актуальность и новизна работы, степень изученности проблемы и обзор источников. Это помогло бы лучше оценить вклад авторов в разработку вопроса о концессионной политике в СССР.

Несомненной заслугой исследователей является включение в монографию большого объема ранее не публиковавшегося источникового материала из центральных архивов
ГА РФ и РГАЭ. Однако остались неохваченными фонды РГАСПИ и местных архивов, которые позволили бы более полно раскрыть противоречия во взаимоотношениях концессионеров с разными органами власти - от местного до центрального уровня.

В первой главе, основываясь на документах центральных органов власти и работах ученых - экономистов и юристов (Н.Д. Кондратьева, В.Н. Шретера, Д.И. Иваницкого и др.). М.М. Загорулько и В.В. Булатов аргументированно доказывают, почему выбор пал на концессионную форму хозяйствования, а не на арендную [6, с. 22-25]. Называя причины предоставления концессий в сельскохозяйственной отрасли и объясняя, почему власти выделили для них преимущественно степные районы, авторы указывали на желание восстановить сельское хозяйство за счет продолжения проведения политики колонизации, начатой еще до революции 1917 г. [6, с. 26, 28-29, 33]. Этим объясняется создание Государственного колонизационного фонда в 1920 г., земли которого служили объектом концессий. На этот факт обращала внимание и Т.Н. Плохотнюк в своих статьях [11, с. 219-220; 12, с. 90].

Рассматривая субъекты концессионной деятельности иностранцев, авторы обратили внимание на то, что она осуществлялась в разных формах [5, с. 56-57]. При этом отмечено незначительное влияние на развитие аграрного сектора таких форм, как иммигрантские коммуны, религиозные и благотворительные организации [6, с. 62-66, 74-77, 80].

Среди успешных форм концессий ученые выделили земледельческие, торговые и перерабатывающие. Несмотря на то что были указаны восемь сельскохозяйственных концессионных предприятий, работавших в СССР, подробнее они остановились на анализе только четырех. Свой выбор авторы обосновали тем, что: 1) концессии вели свою деятельность на территории РСФСР; 2) располагались они в южных и юго-восточных территориях России. Соглашаясь с авторами, мы бы добавили, что эти концессии объединяла форма хозяйствования - земледельческо-скотоводческая.

Вторая глава, в которой исследуется хозяйственная деятельность германской концессии «Маныч», начинается с момента заклю- 
чения концессионного договора акционерного общества «Фридриха Круппа в Эссене»с РСФСР в 1923 году. Здесь авторы в основном сосредоточились на причинах заключения фирмой Круппа концессионного договора с советскими властями и подтвердили позицию Д.А. Марьина, что фирма искала новые рынки сбыта [9, с. $238 ; 5$, с. 87-88]. К сожалению, они не стали рассматривать процесс переговоров между фирмой и советскими властями, раскрывающий сложность взаимопонимания между ними, что было сделано нами и М. Шмидер [4; 5; 18].

Особо хочется отметить достаточно подробный анализ статистических показателей: урожайности зерновых культур, механической и живой тягловой силы, прибыли и убытков. Это дало возможность проследить путь, который прошла концессия «Маныч» от убыточности до повышения рентабельности предприятия к 1933 г., когда прибыль составила 462,5 тыс. руб. [6, с. 107]. Если предприятие развивается, то почему его ликвидировали? Развернутый ответ на этот вопрос авторами не дан.

Наиболее удачными, на наш взгляд, являются третья и четвертая главы, посвященные деятельности субконцессии «Друаг» и смешанной концессии «Прикумского русско-американского товарищества». В них на основе большого архивного материала М.М. Загорулько и В.В. Булатов сумели показать, в каких условиях прорабатывались проекты договоров, какие вопросы были наиболее значимы для концессионеров и советских властей, как разрешались конфликтные ситуации.

Авторы обратили внимание на то, что концессионное предприятие «Друаг» изначально было обречено на провал. Подтверждением тому являлось неэффективное использование земли и неустойчивое финансовое положение, сложившееся из-за несоблюдения советскими властями условий договора и из-за высокого процента по ссуде «Немволбанка» $(40 \%)[6$, c. $124-126]$.

Положение «Прикумского русско-американского товарищества» было значительно лучше. Обеспеченность машинами и сельскохозяйственным оборудованием была почти $100 \%$. Несмотря на увеличение оборотного капитала, для развития предприятия требова- лись дополнительные денежные вливания. Исследователи, анализируя статистические данные, пришли к выводу, что в отличие от «Друага» на этой концессии договор нарушался иностранной стороной. Невыполнение ею финансовых обязательств привело к форме концессии, известной как «вхождение иностранного капитала пайщиком в госпредприятие» [6, с. 146-147].

В пятой главе речь идет о наиболее успешно развивавшейся концессии «Друзаг», которая должна была стать образцовым семеноводческим хозяйством. Многочисленные обследования концессии и отчеты представителей советской власти свидетельствовали о том, что концессия, пройдя стадию убыточности, смогла увеличить основной капитал в два раза. Кроме того, руководством были проведены работы по улучшению жилищно-бытовых условий рабочих и служащих, налаживались контакты с местным населением. Эти факты отмечали и другие авторы [4, с. $130 ; 16$, с. 235 ; 17, с. 176]. Однако смена политического курса свела на нет все положительные результаты.

В шестой главе исследователи показали, в каком состоянии находилась тракторная промышленность и какую роль в ее развитии сыграли концессионные предприятия. С помощью статистических данных им удалось определить численность тракторов, купленных за границей и произведенных внутри страны, отмечался дефицит механизаторов, а также нехватка топлива и запчастей. Но именно дальнейшее развитие тракторостроения будет возможно благодаря усвоению зарубежного опыта от иностранных концессий.

В 2017 г. германский историк Марина Шмидер опубликовала работу «“Fremdkörper im Sowjet-Organismus". Deutsche Agrarkonzessionen in der Sowjetunion 1922-1934» («Инородное тело» в советском организме. Немецкие аграрные концессии в Советском Союзе 19221934»), которая существенно дополнила российские исследования. Данное исследование посвящено участию германских капиталов в развитии сельского хозяйства СССР на территории Северного Кавказа и Поволжья в форме концессий.

Источниковая база монографии основана на документах 36 германских и 15 российских фондов из 13 архивов, не только центральных, 
но и местных. Автором также были привлечены материалы немецкой периодической печати, статистические данные и документы личного происхождения (как немецких государственных деятелей, так и бывших работников«невозвращенцев» Берлинского торгпредства). М. Шмидер в исследовании использует не только немецкую литературу, но и широкий круг работ советских и российских исследователей.

В структурном плане монография состоит из двенадцати глав, которые разделены на подглавы, заключения. Кроме того, в ней содержатся статистические таблицы и многочисленные пояснения.

Во введении, которое обозначено как глава первая, М. Шмидер обращается к толкованию термина «концессия» с позиции советских и немецких властей, а также анализирует историографию проблемы. Она указывает на то, что в Германии и России было опубликовано много работ, которые в основном затрагивали экономико-правовые аспекты деятельности концессий. В целом исследователи стремились выявить значение концессий для развития народного хозяйства СССР, но их влияние на экономическое развитие Германии не рассматривалось. Автор ставил своей целью выяснить, как немецкие концессии помогли укрепить сотрудничество между Германией и Советским Союзом и способствовали развитию германской экономики, удалось ли внедрить капиталистические методы хозяйствования на концессиях [18, S. 23-24].

Во второй главе, анализируя условия концессионной политики, автор указывает на то, что не только СССР преследовал свои цели, проводя концессионную политику, но и Германия. При этом германские предпринимательские круги советское правительство и подчиненные ему институты считали ненадежными. Немцы скептически относились к гарантиям, заявленным советским правительством: «как долго могут быть сохранены исключительные привилегии в пользу иностранцев, в которых отказано самим русским» $[18$, S. 32]. Поэтому немецкие эксперты советовали соотечественникам не участвовать ни в концессиях, ни в смешанных обществах [18, S. 27]. Однако нужда в сельскохозяйственном сырье и рынках сбыта промышленной продукции вынуждала политические круги Германии занять собственную позицию по данному вопросу. Об этом же писали российские исследователи Д.А. Марьин, М.М. Загорулько и В.В. Булатов, И.С. Блинов [1, с. 294-295; 6, с. 87; 9, с. 233]. Официальной целью германской политики в ближайшее время должно было стать экономическое восстановление России [18, S. 44].

В третьей главе рассматриваются концессионные проекты в аграрном секторе. Как и российские историки, она отмечала, что обращение советских властей к сельскохозяйственным концессиям было обусловлено ликвидацией голода и необходимостью восстановления сельского хозяйства [4-6; 11]. Ожидалось, что в этой отрасли иностранные компании помогут сократить безработицу и механизировать труд $[18$, S. 51].

Заинтересованность немецких машиностроительных заводов в российских концессиях объяснялась сложной финансовой ситуацией и узостью рынка сбыта в Германии. Появлялась возможность протестировать различное оборудование и тракторы в соответствии с российскими условиями. В то же время это была своеобразная реклама: «каждый произведенный в Германии продукт, который сегодня попадет в Россию, будет продолжать продвигать немецкие товары и вести к более поздним поставкам» [18, S. 55].

Сельскохозяйственные концессии были наиболее востребованы немецкими компаниями. Они экспортировали в 1925-1928 гг. от $45-50 \%$ российского импорта семян [18, S. 58]. По этому поводу Тило фон Вильмовский писал Густаву фон Болену: «В обозримом будущем они боятся наводнения нашего зернового рынка российскими продуктами и поэтому хотят иметь свои интересы в российском сельском хозяйстве» $[18, \mathrm{~S} .59]$.

В четвертой главе М. Шмидер проанализировала методы управления и кадровую политику немецкой администрации на сельскохозяйственных предприятиях, а также уделила внимание условиям труда и жизни немецких рабочих и служащих. Немецким историком подтверждается точка зрения российских исследователей, что советское правительство таким образом боролось с безработицей и за привилегии рабочего класса $[5 ; 16 ; 17]$, особенно тех, которые являлись членами партийной ячейки или профсоюза, что для концесси- 
онера не имело значения. Об этом более подробно, на примерах многочисленных концессий, писала Т.В. Юдина [16, с. 275-353]. Однако предприниматели концентрировали внимание на собственных принципах отбора персонала и трудовой дисциплине [18, S. 103]. В частности, на концессии «Маныч» использовалась система Тейлора, которая позволяла рационально распределять нагрузку.

Как и российские ученые, М. Шмидер считает, что условия жизни и оплата труда немецких специалистов были значительно выше, чем советских, из-за их высокой профессиональной квалификации. Основательный анализ этих социально-трудовых аспектов представлен в работе Т.В. Юдиной [16, с. 172 238]. М. Шмидер выделены причины, по которым иностранцы приезжали на работу в СССР: финансовые проблемы, растущая безработица в Германии, а также жажда приключений и любопытство. Хотя были многочисленные жалобы в письмах на нехватку чистой воды, наличие мышей, малярию и отсутствие промышленных товаров, оставлять работу в Советском Союзе они не желали.

Несмотря на высокие инвестиции, концессии постоянно нуждались в капитале, что отмечали и российские ученые (см., например: [5; 6]). Сумма займов, взятых в Германии, превышала суммы вкладов акционеров. Исследователь, сравнивая данные российских и немецких архивов, подтверждает мнение российских ученых, что финансовые трудности концессий были вызваны слишком оптимистичными расчетами рентабельности, где не учитывались неурожаи, затраты на ремонт и строительство ирригационных систем и зданий, неблагоприятные тарифы на топливо и транспорт, а также неудачным размещением акций и уходом ключевых деловых партнеров [18, S. 122]. Кроме того, к падению доходности привели управленческие ошибки, инфляция, бюрократические препоны и незнание местных условий хозяйствования [18, S. 132].

В пятой и шестой главах немецкий историк раскрывает причины, по которым германские власти согласились на санацию концессий «Друзаг» и «Маныч». Германский МИД вынужден был согласиться субсидировать концессии, чтобы улучшить советско-германские отношения. Напряженность в них возник- ла после подписания Локарнского договора [18, S. 134]. Кроме того, успешная работа директора «Друзаг» Дитлова способствовала развитию сельского хозяйства Германии, благодаря импорту племенного скота и адаптации немецких злаков к российским условиям.

При этом концессия «Друаг» не была поддержана германским правительством по ряду причин: из-за чрезмерной задолженности, бесперспективности получения прибыли и отсутствия помощи со стороны советского правительства.

Главы с седьмой по двенадцатую посвящены сложностям работы концессии «Друзаг» после реорганизации и обстоятельствам сворачивания ее деятельности. Автор подчеркивает, что из всех немецких концессий она была более успешной, и соглашается с российскими историками в том, что в связи с отказом от НЭПа и установлением фиксированной цены на зерно в концессионной деятельности начинается кризис.

Исключительное положение «Друзаг», конкурентоспособность предприятия, отказ директора придерживаться ценовой политики советской власти и его приверженность рыночным механизмам в экономике, а не принципам плановой системы социалистического государства вызывало негативную реакцию со стороны местных властей, что приводило к постоянному кризису. Так, до 1929 г. Дитлову удавалось продавать зерновые по рыночной стоимости $-2,35$ р. вместо 1,25 р. [18, S. 196]. Для этого им была создана торговая сеть для распространения продукции со вспомогательных предприятий: кирпичного завода, мельниц. Кроме того, Дитлов проводил многочисленные махинации: покупал за границей червонец и нелегально ввозил его в СССР; часть зерна и шерсти перерабатывал внутри концессии, а не за ее пределами, согласно концессионному договору; смешивал шерсть с хлопком (в соотношении 70 / 30), продавая ее потом государственным организациям.

Немецкий историк считает, что значительный вклад в разрушение рабочей атмосферы между германской администрацией и советскими рабочими внесли партийные ячейки и профсоюзы. Это подтверждается ростом партийных членов на концессии. Например, в 1928 г. насчитывалось 14 членов, 5 кандида- 
тов и 10 комсомольцев, а к 1930 г. их численность достигла 60 членов партии и кандидатов и 40 комсомольцев $[18$, S. 206]. В качестве орудия партии выступали профсоюзы, которые, по мнению германского консула Стефани, должны были скрыть диктатуру партии перед внешним миром. В тех случаях, когда партия не хотела появляться на публике, влияние оказывалось под нейтральным флагом профсоюзов [18, S. 204].

От противостояния концессионера и советских органов власти страдали не только советские рабочие и служащие, но и немецкие. Члены профсоюза были запуганы и послушны, а немецкие служащие должны были «действовать правильно», чтобы иметь возможность доказать свои права в суде. Высокие требования профсоюза к заработной плате и строительству помещений, подстрекательство работников, а также широкие полномочия по кадровым вопросам вызывали у концессионеров трудности, которые они не всегда могли успешно решить путем арбитража.

Как и российские исследователи, автор отметила, что советская власть искала подходящие способы ликвидации концессий. Поэтому было проведено нескольких трудовых судебных процессов против администрации концессии, инициированных советскими властями в начале 1930-х гг., с целью запугивания. Кроме того, они прибегали к излюбленной практике - штрафам [18, S. 238]. Но основной проблемой было получение разрешения на перевод валюты. Представители концессии отмечали, что попытки вести переговоры с региональными органами власти не такие приятные, как в Москве: «Горизонт здесь слишком узкий и маленький» $[18, \mathrm{~S} .261]$.

М. Шмидер сделала справедливое наблюдение о том, что сворачивание деятельности ряда немецких концессий в 1933 г. было обусловлено не только экономическими, но и внешнеполитическими причинами и вопросами безопасности. Директор Дитлов дискредитировал советскую власть, которая отрицала голод на юге страны, представив на суд германской общественности фотографии, сделанные во время поездок. Концессионер во время голода не только давал работу голодающим российским немцам Северного Кавказа, но и организовывал бесплатные обеды на территории концессии и выдавал продуктовые карточки детям. К тому же помогал местному немецкому населению укрывать от властей сельскохозяйственную продукцию на своей территории.

После ликвидации концессии немецким сотрудникам разрешили вернуться в Германию, часть советских сотрудников была уволена, а более 160 человек арестованы и обвинены в национал-социалистических настроениях [18, S. 293-294]. Во время Второй мировой войны Германией были привлечены к работе на оккупированных территориях СССР бывшие сотрудники концессий: Ф. Дитлов, Х. Штал, Э. фон Богуславский, О. Шиллер и Р. Ваймерт.

Результаты. Представленный обзор двух ключевых, по нашему мнению, за последнее время работ - М.М. Загорулько, В.В Булатова «Наркомземовские концессии. Сельское хозяйство и водные промыслы» (Волгоград, 2010) и M. Schmieder "“Fremdkörper im SowjetOrganismus". Deutsche Agrarkonzessionen in der Sowjetunion 1922-1934» (Stuttgart, 2017) - позволяет заключить, что изучение концессионной политики СССР в сельском хозяйстве продолжает находить своих исследователей как в России, так и за рубежом. В монографиях продемонстрирована большая работа авторов по систематизации и анализу архивного материала.

М.М. Загорулько и В.В. Булатов пришли к выводу, что, приступая к работе в России, концессионеры не всегда представляли себе реальную ситуацию - необходимые размеры оборотных средств, природно-климатические условия, сложность взаимоотношений с властями. Однако те из них, кто смог справиться с трудностями и внести коррективы в свою работу, превратились в образцово-показательные хозяйства.

М. Шмидер удалось охарактеризовать деятельность немецких концессий и их взаимоотношения с центральными и местными органами власти. Ею было акцентировано внимание на эффективных методах хозяйствования концессий и выстраивании отношений администрации концессий с рабочими и служащими. Значительный источниковый материал позволил выявить причины 
заинтересованности германских властей в создании и ликвидации концессий. М. Шмидер пришла к выводу, что в основе политики Германии сначала лежали экономические, а потом уже политические факторы. Большое влияние на ход концессионного дела двух государств оказали их внешнеполитические отношения. Периоды ликвидаций германских концессий и показательных судов над концессионерами приходились на время советскогерманских внешнеполитических кризисов зиму 1929/30 г. и весны - лета 1933 г. - после прихода к власти в Германии НСДАП.

Достоинствами обеих работ является не только введение в научный оборот новых источников из германских и российских архивов, но и привлечение значительного объема статистики, обработанной с применением квантитативных методов исследования, что, без сомнения, служит примером для дальнейшего изучения вопросов развития экономики СССР XX века. Кроме того, концессионный опыт может быть востребован в современных условиях для возрождения сельского хозяйства страны.

\section{СПИСОК СОКРАЩЕНИЙ}

ГА РФ - Государственный архив Российской Федерации.

НСДАП-Национал-социалистическая немецкая рабочая партия.

РГАСПИ- Российский государственный архив социально-политической истории.

РГАЭ - Российский государственный архив экономики.

\section{СПИСОК ЛИТЕРАТУРЫ}

1. Блинов, И. С. Сельскохозяйственная концессия германской фирмы «Фридрих Крупп» в СССР (1922-1928 гг.) / И. С. Блинов // Преподаватель XXI век. - 2019. - № 4. - С. 292-301.

2. Ерохина, О. В. Германская концессия «Маныч» в Советской России (1922-1934 гг.) / О. В. Ерохина // Новый исторический вестник. - 2009. № 22 (4). - С. 34-41.

3. Ерохина, О. В. Концессионная политика Советского государства и сельскохозяйственная концессия «Друзаг» в 20-30-е гг. ХХ в. / О. В. Ерохина // Федерализм. Теория. Практика. История. 2009. - № 1 (53). - С. 93-103.
4. Ерохина, О. В. Германские сельскохозяйственные концессии Северо-Кавказского края в первые десятилетия советской власти / О. В. Ерохина // Экономическая история : Ежегодник. 2011/12. - М. : Рос. полит. энцикл. (РОССПЭН), 2012. - C. 98-148.

5. Ерохина, О. В. Немецкие предприниматели в хозяйственном комплексе юга России. 1860-е 1930-е гг. / О. В. Ерохина. - М. : МПГУ, 2018. - 332 с.

6. Загорулько, М. М. Наркомземовские концессии. Сельское хозяйство и водные промыслы / М. М. Загорулько, В. В. Булатов - Волгоград : Волгогр. науч. изд-во, 2010. - 480 с.

7. Курысь, Н. В. Иностранные инвестиции : Российская история (правовое исследование) / Н. В. Курысь. - СПб. : Юрид. центр Пресс, 2003. - 219 с.

8. Леденев, А. С. Концессии периода нэпа: правовые аспекты регулирования / А. С. Леденев. М. : РУДН, 2008. - 178 c.

9. Марьин, Д. А. Россия и Германия: опыт экономического сотрудничества : (На примере фирмы «Фридрих Крупп) / Д. А. Марьин // Экономическая история России: проблемы, поиски, решения : ежегодник. - Волгоград : Изд-во ВолГУ, 2004. Вып. 6. - С. 231-250.

10. Марьясова, Н. В. Иностранный капитал на Дальнем Востоке России в 20-30-е годы (концессии и концессионная политика советского государства) / Н. В. Марьясова. - Владивосток : Изд-во ДВГУ, 2000. $-167 \mathrm{c}$.

11. Плохотнюк, Т. Н. Германские сельскохозяйственные концессии на Северном Кавказе (19201930-е гг.) / Т. Н. Плохотнюк // Немцы России и СССР : 1901-1941 гг. : материалы Междунар. науч. конф. (Москва, 17-19 сент. 1999 г.). - М. : Готика, 2000. - C. 217-225.

12. Плохотнюк, Т. Н. Колонизационная сельскохозяйственная концессия акционерного общества «Фридрих Крупп» в России: о причинах и обстоятельствах создания (к истории развития советскогерманских отношений в 1920-е годы) / Т. Н. Плохотнюк // Международные отношения XX века в исторических судьбах стран Европы и Северной Америки. Ставрополь : Ассоц. всемир. истории ; Пятигорск : Пятигор. гос. лингв. ун-т, 2004. Вып. 1. - С. 89-103.

13. Поткина, И. В. Правовое регулирование предпринимательской деятельности в России, XIX первая четверть ХХ в. / И. В. Поткина. - М. : Норма, 2009. - 304 c.

14. Рагер, Ю. Б. О германо-советской концессии «Друзаг» в Ванновском немецком районе Северо-Кавказского края / Ю. Б. Рагер // Российские немцы на Дону, Кавказе и Волге : материалы Рос.-Герм. науч. конф. (Анапа, 22-26 сент. 1994 г.). - М. : Готика, 1995. - C. 73-78. 
15. Ширяева, Е. Г. Сельскохозяйственные иностранные концессии на Северном Кавказе в 1920-х 1930-х и в 1990-х - начале 2000-х гг.: историко-сравнительный анализ : дис. ... канд. ист. наук / Ширяева Елена Григорьевна. - Ростов н/Д : [б. и.], 2012. -221 с.

16. Юдина, Т. В. Советские рабочие и служащие на концессионных предприятиях СССР в годы НЭПа / Т. В. Юдина. - Волгоград : Изд-во ВолГУ, 2009. $-444 \mathrm{c}$.

17. Юдина, Т. В. Рабочие на концессионных предприятиях Российской империи и СССР (19001940-е гг.) / Т. В. Юдина, В. В. Булатов, Е. Л. Фурман. - Волгоград : Изд-во ВолГУ, 2015. - 210 с.

18. Schmieder, M. "Fremdkörper im SowjetOrganismus". Deutsche Agrarkonzessionen in der Sowjetunion 1922-1934 / M. Schmieder. - Stuttgart : Franz Steiner Verl., 2017. - 340 S.

19. Schmieder, M. Der Landwirt und Politiker Fritz Dittloff (1894-1954). Vom Direktor der landwirtschaftlichen Reichskonzession Drusag in der Sowjetunion zum Abgeordneten des Niedersächsischen Landtags / M. Schmieder // Halbjahresschrift für südosteuropäische Geschichte, Literatur und Politik. 2016. - Jg. 28, H. 1-2. - S. 23-35.

20. Schlarp, K. H. Deutsche Konzessionen in der Sowjetunion 1922-1933 unter besonderer Berücksichtigung der Landwirtschaft / K. H. Schlarp // Zwischen Lübeck und Novgorod. Wirtschaft, Politik und Kultur im Ostseeraum vom frühen Mittelalter bis ins 20. Jahrhundert : Norbert Angermann zum 60. Geburstag. - Lünenburg : [s. n.], 1996. - S. 441-476.

\section{REFERENCES}

1. Blinov I.S. Sel'skohozyajstvennaya koncessiya germanskoj firmy «Fridrih Krupp» v SSSR (1922-1928 gg.) [Agricultural Concession of the German Firm "Friedrich Krupp" in the USSR (19221928)]. Prepodavatel' XXI vek [Teacher of the XXI Century], 2019, no. 4, pp. 292-301.

2. Erohina O.V. Germanskaja koncessija «Manych» v Sovetskoj Rossii (1922-1934 gg.) [The German Concession "Manych" in Soviet Russia (1922-1934 gg.)]. Novyj istoricheskij vestnik [New Historical Bulletin], 2009, no. 22 (4), pp. 34-41.

3. Erohina O.V. Koncessionnaja politika Sovetskogo gosudarstva i sel'skohozjajstvennaja koncessija «Druzag» v 20-30-e gg. XX v. [Concession Policy of the Soviet State and Agricultural Concession "Druzag" in the 20-30s of the XX Century]. Federalizm. Teorija. Praktika. Istorija [Federalism. Theory. Practice. History], 2009, no. 1 (53), pp. 93-103.

4. Erohina O.V. Germanskie sel'skohozjajstvennye koncessii Severo-Kavkazskogo kraja v pervye desjatiletija sovetskoj vlasti [German Agricultural
Concessions of the North Caucasus Region in the First Decades of Soviet Power]. Jekonomicheskaja istorija: ezhegodnik [Economic History. Yearbook]. 2011/12. Moscow, Russian political encyclopedia. 2012, pp. 98-148.

5. Erohina O.V. Nemeckie predprinimateli v hozyajstvennom komplekse yuga Rossii. 1860-e1930-e gg. [German Entrepreneurs in the Economic Complex of the South of Russia. 1860-1930s]. Moscow, Moscow State Pedagogical University, 2018. 332 p.

6. Zagorul'ko M.M., Bulatov V.V. Narkomzemovskie koncessii. Sel'skoe hozjajstvo $i$ vodnye promysly [Narkomzem Concession. Agriculture and Water Industries]. Volgograd, Volgogradskoe nauchnoe izdatel'stvo, 2010. $480 \mathrm{p}$.

7. Kurys' N.V. Inostrannye investicii: Rossijskaja istorija (pravovoe issledovanie) [Foreign Investments: Russian History (Legal Research)]. Saint Petersburg, Publishing house "Legal center Press", 2003. 219 p.

8. Ledenev A.S. Koncessii perioda nepa: pravovye aspekty regulirovaniya [Concessions of the NEP Period: Legal Aspects of Regulation]. Moscow, Peoples' Friendship University of Russia, 2018. 178 p.

9. Mar'in D.A. Rossija i Germanija: opyt jekonomicheskogo sotrudnichestva (Na primere firmy «Fridrih Krupp [Russia and Germany: The Experience of Economic Cooperation (On the Example of the Firm "Friedrich Krupp"]. Jekonomicheskaja istorija Rossii: problemy, poiski, reshenija: ezhegodnik [Economic History of Russia: Problems, Searches, Solutions. Yearbook]. Volgograd, Izd-vo VolGU, 2004, iss. 6, pp. 231-250.

10. Mar'jasova N.V. Inostrannyj kapital na Dal'nem Vostoke Rossii v 20 - 30-e gody (koncessii $i$ koncessionnaja politika sovetskogo gosudarstva) [Foreign Capital in the Russian far East in the 20-30s (Concessions and Concession Policy of the Soviet State)]. Vladivostok, DVSU Publishing house, 2000. 167 p.

11. Plohotnjuk T.N. Germanskie sel'skohozjajstvennye koncessii na Severnom Kavkaze (1920-1930-e gg.) [German agricultural concessions in the North Caucasus (1920-1930)]. Nemcy Rossii i SSSR: 1901-1941 gg.: materialy Mezhdunar. nauch. konf. [Germans of Russia and the USSR: 1901-1941. Proceedings of the International Scientific Conference]. Moscow, "Gothic", 2000, pp. 217-225.

12. Plohotnjuk T. N. Kolonizacionnaya sel'skohozyajstvennaya koncessiya akcionernogo obshchestva «Fridrih Krupp» v Rossii: o prichinah i obstoyatel'stvah sozdaniya ( $\mathrm{k}$ istorii razvitiya sovetsko-germanskih otnoshenij v 1920-e gody) [Colonization Agricultural Concession of the JointStock Company "Friedrich Krupp" in Russia: About the Reasons and Circumstances of Creation (To the 


\section{СОВЕТСКАЯ ВЛАСТЬ В 1920-х - ПЕРВОЙ ПОЛОВИНЕ 1930-х ГГ.}

History of the Development of Soviet-German Relations in the 1920s)]. Mezhdunarodnye otnosheniya $X X$ veka $v$ istoricheskih sud'bah stran Evropy i Severnoj Ameriki [International Relations of the Twentieth Century in the Historical Destinies of the Countries of Europe and North America]. Stavropol, Pyatigorsk, 2004, vol. 1, pp. 89-103.

13. Potkina I.V. Pravovoe regulirovanie predprinimatel'skoj dejatel'nosti v Rossii, XIX-pervaja chetvert' $X X v$. [Legal Regulation of Entrepreneurial Activity in Russia, XIX - the First Quarter of the XX Century]. Moscow, Norm Publ., 2009.304 p.

14. Rager Ju.B. O germano-sovetskoj koncessii «Druzag» v Vannovskom nemeckom rajone SeveroKavkazskogo kraja [On the German-Soviet Concession "Druzag" in the Vannovsky German District of the North Caucasus Region]. Rossijskie nemcyna Donu, Kavkaze i Volge: materialy Ros.-Germ. nauch. konf. [Russian Germans on the Don, Caucasus and Volga. Materials of the Russian-German Scientific Conference. Anapa, 2226 September 1994]. Moscow, "Gothic", 1995, pp. 73-78.

15. Shiryaeva E.G. Sel'skohozyajstvennye inostrannye koncessii na Severnom Kavkaze v 1920-h - 1930-h iv 1990h-nachale 2000-h gg.: istoriko-sravnitel'nyj analiz: dis. ... kand. ist. nauk [Agricultural Foreign Concessions in the North Caucasus in the 1920s-1930s and in the 1990s-early 2000s: Historical and Comparative Analysis. Cand. hist. sci. diss.]. Rostov-on-Don, 2012.221 p.
16. Judina T.V. Sovetskie rabochie $i$ sluzhashhie na koncessionny hredprijatijah SSSR $v$ gody $\mathrm{NJePa}$ [Soviet Workers and Employees at Concession Enterprises of the USSR During the NEP]. Volgograd, Izd-vo VolGU, 2009. $444 \mathrm{p}$.

17. Judina T.V. Bulatov V.V., Furman E.L. Rabochie na koncessionnyh predprijatijah Rossijskoj imperii $i$ SSSR (1900-1940-e gg.) [Workers at Concession Enterprises of the Russian Empire and the USSR (1900s-1940s)]. Volgograd, Izd-vo VolGU, 2015. $210 \mathrm{p}$.

18. Schmieder M. «Fremdkörper im SowjetOrganismus». Deutsche Agrarkonzessionen in der Sowjetunion 1922-1934. Stuttgart, Franz Steiner Verlag, 2017.340 S.

19. Schmieder M. Der Landwirt und Politiker Fritz Dittloff (1894-1954). Vom Direktor der landwirtschaftlichen Reichskonzession Drusag in der Sowjetunion zum Abgeordneten des Niedersächsischen Landtags. Halbjahresschrift für südosteuropäische Geschichte, Literatur und Politik, 2016, Jg. 28, H. 1-2, S. 23-35.

20. Schlarp K.H. Deutsche Konzessionen in der Sowjetunion 1922-1933 unter besonderer Berücksichtigung der Landwirtschaft. Zwischen Lübeck und Novgorod. Wirtschaft, Politik und Kultur im Ostseeraum vom frühen Mittelalter bis ins 20.Jahrhundert: Norbert Angermann zum 60. Geburstag. Lünenburg, 1996, S. 441-476.

\section{Information About the Author}

Ol'ga V. Erokhina, Doctor of Sciences (History), Associate Professor, Professor, Department of Russian History, Moscow Pedagogical State University, Prosp. Vernadskogo, 88, 119571 Moscow, Russian Federation, ov.erokhina@mpgu.su, https://orcid.org/0000-0001-5158-7110

\section{Информация об авторе}

Ольга Викторовна Ерохина, доктор исторических наук, доцент, профессор кафедры истории России, Московский педагогический государственный университет, просп. Вернадского, 88, 119571 г. Москва, Российская Федерация, ov.erokhina@mpgu.su, https://orcid.org/0000-0001-5158-7110 